\title{
Including product features in process redesign
}

\author{
Hvam, Lars; Hauksdóttir, Dagný; Mortensen, Niels Henrik; Haug, Anders
}

Published in:

Concurrent Engineering: Research and Applications

Link to article, DOI:

$10.1177 / 1063293 \times 17727327$

Publication date:

2017

Document Version

Peer reviewed version

Link back to DTU Orbit

Citation (APA):

Hvam, L., Hauksdóttir, D., Mortensen, N. H., \& Haug, A. (2017). Including product features in process redesign. Concurrent Engineering: Research and Applications, 25(4), [1063293X1772732].

https://doi.org/10.1177/1063293X17727327

\section{General rights}

Copyright and moral rights for the publications made accessible in the public portal are retained by the authors and/or other copyright owners and it is a condition of accessing publications that users recognise and abide by the legal requirements associated with these rights.

- Users may download and print one copy of any publication from the public portal for the purpose of private study or research.

- You may not further distribute the material or use it for any profit-making activity or commercial gain

- You may freely distribute the URL identifying the publication in the public portal

If you believe that this document breaches copyright please contact us providing details, and we will remove access to the work immediately and investigate your claim. 


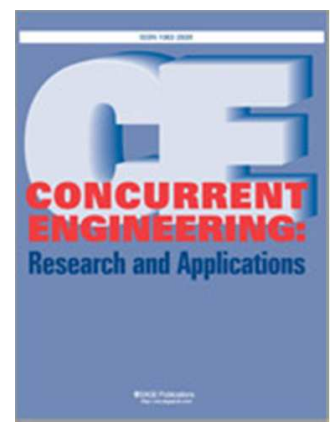

\section{Including Product Features in Process Redesign}

\begin{tabular}{|c|c|}
\hline Journal: & Concurrent Engineering: Research and Applications \\
\hline Manuscript ID & CERA-16-0067.R2 \\
\hline Manuscript Type: & Standard Article \\
\hline Date Submitted by the Author: & $\mathrm{n} / \mathrm{a}$ \\
\hline Complete List of Authors: & $\begin{array}{l}\text { Hvam, Lars; Technical University of Denmark, Management Engeering } \\
\text { Hauksdóttir, Dagný; Technical University of Denmark, Department of } \\
\text { Mechanical Engineering } \\
\text { Mortensen, Niels; Technical University of Denmark, Department of } \\
\text { Mechanical Engineering } \\
\text { Haug, Anders; University of southern Denmark, Institute for } \\
\text { entrepreneurship and relation management }\end{array}$ \\
\hline Keywords: & $\begin{array}{l}\text { product modelling, process modelling, engineering processes, integrated } \\
\text { product and process modelling, process re-engineering, engineering } \\
\text { design, product configuration }\end{array}$ \\
\hline Abstract: & $\begin{array}{l}\text { This article suggests a visual modelling method for integrating models of } \\
\text { product features with business process models for redesigning the business } \\
\text { processes involving specifications of customer-tailored products and } \\
\text { services. The current methods for redesigning these types of business } \\
\text { processes do not take into account how the product features are applied } \\
\text { throughout the process, which makes it difficult to obtain a comprehensive } \\
\text { understanding of the activities in the processes and to generate significant } \\
\text { improvements. The suggested approach models the product family using } \\
\text { the so-called product variant master and the Business Process Modelling } \\
\text { Notation (BPMN) for modelling the process flow. The product model is } \\
\text { combined with the process map by identifying features used in each step of } \\
\text { the process flow. Additionally, based on the information absorbed from the } \\
\text { integrated model, the Value Stream Mapping (VSM) modelling technique is } \\
\text { applied to the specification process to evaluate its performance in } \\
\text { quantifiable terms. The proposed modelling approach was investigated } \\
\text { through three case studies. Experiences from the case studies were that } \\
\text { the suggested modelling techniques gave additional insight into the } \\
\text { specification processes and formed a good basis for process improvement. } \\
\text { Furthermore the case studies indicated that the suggested modelling } \\
\text { techniques were applicable and easy to use. }\end{array}$ \\
\hline
\end{tabular}




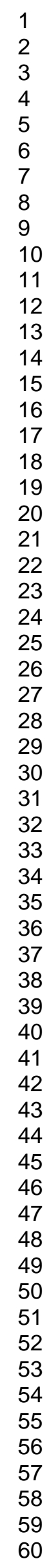

SCHOLARONE ${ }^{m}$

Manuscripts

10

11

12

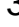

16

17

20

21

23

24

27

28

30

31

34

35

36

39

40

41

42

44

45

46

47

48

50

51

52

56

57

59

60

http://mc.manuscriptcentral.com/cera 


\title{
Including Product Features in Process Redesign
}

\begin{abstract}
This article suggests a visual modelling method for integrating models of product features with business process models for redesigning the business processes involving specifications of customer-tailored products and services. The current methods for redesigning these types of business processes do not take into account how the product features are applied throughout the process, which makes it difficult to obtain a comprehensive understanding of the activities in the processes and to generate significant improvements. The suggested approach models the product family using the so-called product variant master and the Business Process Modelling Notation (BPMN) for modelling the process flow. The product model is combined with the process map by identifying features used in each step of the process flow. Additionally, based on the information absorbed from the integrated model, the Value Stream Mapping (VSM) modelling technique is applied to the specification process to evaluate its performance in quantifiable terms. The proposed modelling approach was investigated through three case studies. Experiences from the case studies were that the suggested modelling techniques gave additional insight into the specification processes and formed a good basis for process improvement. Furthermore the case studies indicated that the suggested modelling techniques were applicable and easy to use.
\end{abstract}

Keywords: product modelling; process modelling, integrated product and process modelling, process reengineering, engineering design, product configuration, engineering processes.

\section{Introduction}

A specification process is a business process in which specifications for products and how products are being produced, shipped, installed, used, serviced and scrapped are generated. Product drawings, lists of parts, assembly instructions, service manuals etc. are examples of the outputs of specification processes. Examples of 
specification processes are a process for making quotations, or a process for making BOM's and product drawings (Jiao et al., 2000; Forza and Salvador, 2008; Zhang 2010; Hvam et al., 2013). Specification processes typically include multiple departments at different locations, information handovers, scattered information systems, different technical backgrounds and languages, potentially leading to unpredictable delivery times, a lack of overview and a risk of processing errors (Kritchanchai and MacCarthy, 1999; Burgess et al., 2005; Tenhiala and Ketokivi, 2012). The activities in the specification processes are characterized by having a relatively well-defined space of (maybe complex) solutions as a contrast to product development, which is a more creative process (Schwarze 1996; Browning and Rameseh, 2007; Hopp et al., 2009; Hvam et al. 2008).

Several well-established modelling methods have been provided for the purpose of analysing and outlining business processes in general and product families (as the literature review in section 2 reveals). This article proposes an approach for integrating the modelling of product features with the modelling and redesign of specification processes. Existing approaches for product modelling and for process mapping have been widely applied, but no modelling techniques combining the two in a way that provides sufficient visual overview to support the redesign of the specification process have been found (Grover and Malhotra, 1997; Li and Rajagopalan, 2008). The current methods for redesigning specification processes do not take into account the product features used in these processes, which makes it difficult to obtain the required understanding of the process activities and to come up with significant improvements.

To address this issue, this paper proposes an Integrated Process and Product Modelling (IPPM) technique. The development and tests of this modelling technique address the following questions:

1) Is it possible to model the product features used in each step in a specification process with sufficient visual overview?

2) If it is possible, what insight will it bring to the specification processes?

3) Based on this insight, how can the IPPM support the development of new specification processes?

4) Is it possible to use VSM to measure the performance of a specification process?

The suggested approach for integrated modelling of specification processes and product features was investigated through three case studies. 
The remainder of the paper is structured as follows. First relevant literature is reviewed in section 2. On this basis, the paper proposes an IPPM technique in section 3. Next, the research method is described in section 4. Hereafter, the paper presents a case study (in section 5) that demonstrates the use of the proposed approach, after which the results from this and two other cases are described. Next the results of the studies are discussed in section 6. Finally, conclusions are drawn in section 7.

\section{Literature review}

The suggested modelling method is based on existing literature on business process modelling and product modelling, which are discussed in the following subsections. Furthermore, a literature study has been conducted for existing proposals for integration of product and process modelling.

\subsection{Business Process Modelling}

Business process modelling is the activity of representing the processes of an organisation so that they can be analysed, improved, designed and/or communicated (Biazzo, 2000). Several notations and tools for business process modelling exist. The most frequently used and widely accepted tool for mapping processes has been the flowchart. Flowcharting provides an immediate understanding of the basic principles behind a process's methodology (Khan, 2004; Damij, 2007; Klotz et al., 2008; Nash and Poling, 2009; Prasad, 2016). More specific widespread techniques include the Unified Modelling Language (UML) activity diagram, IDEF, ebXML BPSS, BPEL, EPC, Gantt Charts and the Design Structure Matrix (DSM) (White, 2004; Rosemann et al., 2009; Recker et al., 2005; Nilsson and Fagerström, 2003; Luh et al., 2011). A major challenge in the area of business process modelling has been to evaluate the appropriateness and the expressive capabilities of these models (Rosemann et al., 2009; Recker et al., 2005) and to reduce the fragmentation that exists within BPM notations (Ko et al., 2009). The BPM notations applied in the framework presented in this paper are the Business Process Modelling Notation (BPMN) and VSM.

The Business Process Management Initiative (BPMI) has developed a standard BPMN which has been proposed as the new process modelling industry standard for flowchart modelling (White, 2004; BPMI, 2011). The notation has strong expressive capabilities as it provides standard item types for different categories of 
process elements. One of its strengths is that it includes lanes that communicate which actor performs which activities. This is an important feature for the modelling of the specification process as it clearly distinguishes the responsibilities of the different process participants and handover of information.

A commonly used technique for process performance analysis in relation to production processes is Value Stream Mapping (VSM). The VSM is specially designed to communicate process performance in terms of lead time and so-called non-value-adding activities, i.e. activities that do not provide any value to the customer (Rother and Shook, 1998; Lasa et al., 2008). When applying a VSM, both the current and future states of the process are outlined in order to evaluate improvement options (Lovelle, 2001; Browing and Ramasesh, 2007). The main benefit of this modelling technique is that it models the whole value chain in one map enabling the business developers to retain an objective view and focus on improving the process steps that have the potential for the biggest performance gain (Holweg, 2005).

Traditional applications of VSM have primarily focused on the physical transformation of the product in the manufacturing process (Barber and Tietje, 2008), however, VSM is now also being applied in other business processes such as sales, engineering and planning. Furthermore, McManus (2004) reports on the use of VSM in the context of product design, and Barber and Tietje (2008) illustrate how sales processes can be mapped in order to reveal non-value-adding activities. There are however no scientific reports that apply VSM to the specification process. Nevertheless, since the lead time of the specification process directly impacts on the end customer, and due to the possible departmentalisation of the process, it is especially valuable to focus on the performance of the end-to-end business process.

\subsection{Product Modelling}

Product modelling can be interpreted as the logical accumulation of relevant information concerning a given product range, including aspects of the product's life cycle (Andreasen, 1994; Hvam, 2001). Product modelling is used to get an overview of the product assortment and has been widely utilised by enterprises in their product development processes (Yang et al., 2008; Lu et al., 2007). 
Different techniques such as the Standard for Exchange of Product model data (STEP/ ISO10303) (Chan et al., 2003), and UML by the Object Management Group (www.omg.org, Booch, 1999), have been developed to assist the modelling of product information. The product modelling technique applied in this paper is the Product Variant Master (PVM). The PVM is a tool for modelling product families (Hvam et al., 2008; Mortensen, 2011) and is based on three theoretical domains: Object-oriented Modelling (Booch et al., 1999), General Systems Theory (Skyttner, 2005) and modeling mechanical products (Hubka, 1988; Schwarze, 1996). A PVM consists of two parts: a 'part of' model (the left-hand side of the PVM) contains a decomposition of design units which appear in the entire product family, and a 'type of' model (the right-hand side) describes how a product part can appear in several variants. The structure of the PVM can be seen in Figure 1.

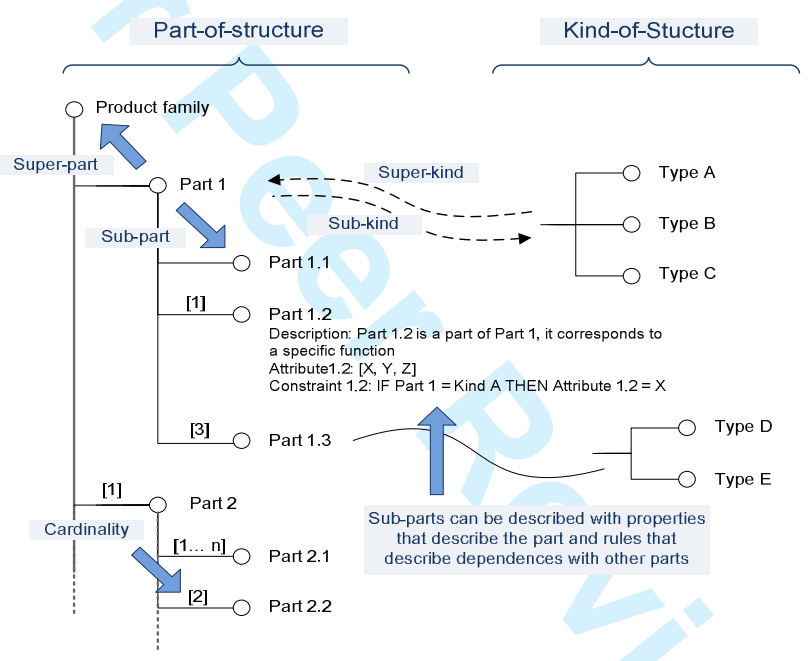

Figure 1: The structure of a PVM (adjusted from Hvam et al., 2008).

In the PVM the product range is modelled from three points of view (Hvam et al., 2008): 1) Customer view that communicates the properties, performance or features of interest to the customer; 2) Engineering view that contains the functional units and solution principles contained in the product or product range; and 3) Production (part) view that contains the physical components to be dealt with in production.

\subsection{Integration of Product and Process Modelling}

A literature search on integration of product and process modelling was conducted in the databases: Web of Science and Scopus. The search was carried out using the phrase "Integrated product and process model*". From 
Web of Science 20 results were obtained and from Scopus 30 results were obtained, 11 of which were overlapping. Several of the papers found directly use the phrase "integrated product and process model/modelling", which indicates that this is the appropriate term for this sub-field of research. Next the following synonyms were replaced for "Integrated": Combined, merged, unified, and incorporated. Only one relevant result, using "combined" was obtained through this search (from Scopus).

The sub-area of integrated product and process model has been addressed in a variety of settings the common denominator being to establish concurrent engineering (Lawson and Karandikar, 1994; Prasad, 1996). In order to be considered competing to the approach presented in this paper, the proposals need to include notations for product and process modelling and a suggestion for how to visually integrate those.

In product development the link between product architecture and manufacturing has been suggested to make the designers more aware of the limitations of the manufacturing process and to optimize quality attributes resulting from the manufacturing or life cycle processes (Tönshoff and Zwick 1998). Reinhart et al. (2014) present a framework for combining the product structure and production processes in the design of EV battery cells, where production processes directly affect the achievable product quality enabling the design of manufacturing systems that result in the optimal product quality. The models are integrated via a correlation matrix, mapping the influences of production parameters on specific product attributes. Leibrecht et al., (2007), integrate expert knowledge to help developers determine the best design options to reduce emissions, for the development of environmentally sound products. The impacts of different product configuration can be analysed for all stages in the lifecycle on the basis of virtual product and process data. Other well established general methods suggesting a link between the product architecture to the manufacturing process for the purpose of Design for Manufacturing are e.g. Axiomatic design (Suh, 1998), House of quality (Houser and Clausing, 1988), Product Family Master Plan (Harlou, 2006). Although these modeling frameworks provide a method for linking product design information to processes there is a fundamental difference to the approach presented in this paper. First, this paper addresses specification processes not manufacturing, second, the aim of integrating the product features with the process model is to obtain an increased insight into how product features are used in the specification process, thus providing a deeper understanding of the activities in the process flow and through 
this, ideas for improving the process. Several contributions with the aim of integrating product and process models have been presented within the field of construction industry (Anumba et al. 2000; Kimmance et al., 2004; Stumpf et al. 1996). Kimmerance et al. (2004) provide sufficient modelling techniques for the product and process model, however, the models are linked electronically using hyperlinks. The users can therefore view and access different type of information in the same user interface, but no visual overview of the interlinking, that could be used for process improvement, is provided.

The method of using hyperlinks or matrixes might be sufficient for the purpose of the targeted applications for the publications presented above, however, the framework presented here has the purpose to provide a platform for accomplishing a common understanding and form a basis for process improvements. This requires a sufficient level of visual communication to motivate those people whose buy in will be needed to support the project. Two methods that provide sufficient description of the product and process modelling notations used and a method to integrate those visually have been identified. Nilsson and Fagerström (2003) investigate how product and process related information could be structured and managed with the aim of bridging the gap between modelling products and processes, with the aim of improving the product development process, e.g. the handling of information. They suggest using IDEF0 and Process Design Structure Matrix (DSM) for process modelling and Product DSM for product modelling. A link is established between clusters of the two DSMs using arrows. This provides limited visabilty and detailed connections are not achived. For a more complicated product family, the overview using arrows would soon be lost.

Hogrebe et al. (2009) establish a conceptual, methodological and technical basis for the development of IPPM for the development of software systems for public administration, traditionally marked by redundant, paper-based forms. The object-oriented Event driven Process Chain (oEPC) modelling concept is used for the process description and a UML Class diagram is used to describe the information classes. The models are linked by listing the information classes and operations from the class diagram, relevant for each process step, in the process model. Unsupported and reoccurring operations are highlighted and form the basis for determining new technical services. This is a visual approach, but this way of re-listing the product elements does not effectively communicate the repeated elements. 
The literature review highlights a gap, in establishing a sufficient visual linking between product and process modelling that can be used to identify and evaluate improvement opportunities for redesigning business process.

\section{An approach for integrated product and specification process reengineering}

In order to enable detailed insights into specification processes, based on the literature study, this paper suggests an approach that integrates product and process models (IPPM). The modelling techniques included in proposed approach are; the PVM technique for product modelling, as it gives a visual overview of the products in focus, and is being used in several companies (Hvam et al., 2008), and the BPMN for business process modelling (White, 2004) as it gives a good visualization of processes and is commonly used for process modelling.

Linking the PVM to the process model reveals where specific product features are used in the process flow and which actor uses these. Furthermore, an ASIS (i.e., 'as the process flow is now') and TOBE (i.e., as the process flow is to be in the future) representation of the product model is suggested in order to form the basis for restructuring the process flow or redefining the product features used in the specification processes.

The main purpose of the process model is to identify the product features specified in each step of the process and the information handovers between different actors. It is therefore important that the BPMN model presents the actors involved in each process step and their interaction.

The relevant activities of the specification process, where product information is processed, have been marked with a number. The product features in the PVM is linked to the process map by marking the feature with the corresponding number that defines the activity in which it is entered or modified. From the numbers specified in the PVM it is now possible to have an overview of all the process steps specifying each product feature. This is intended to reveal who defines the product features and if they are specified at the correct step of the process. The model may reveal information (product features), which is entered too early, too late, or too often. More specifically, if information is entered too early, there is a greater chance that it is incomplete or even incorrect. If information is entered too late, this can imply that subsequent activities cannot be begun, because they need this information. 
Figure 2 illustrates the suggested IPPM. This is a generalised presentation of a typical specification process and model of a product range, based on previous research in industrial companies as outlined in (Forza and Salvador, 2007).

From the example in Figure 2, it can be seen that Option 1 in the customer view is specified in four process steps: 1, 4, 5 and 6, which indicates that it is being re-entered in different specifications or IT systems. On the other hand, Option 2.1 in the customer view is entered in process step 2 by a designer; the designer is therefore defining an option that should be selected by the customer. From the engineering and part view it can be identified that the salesmen are defining a number of solutions and parts (see those that are marked with the numbers 1,3 or 4 ). This reveals that the salesmen are specifying information for which they may not possess technical knowledge. Process steps that do not specify any new information (in this particular example, it is process step 4) can be identified from the IPPM. The identification of the process steps that do not involve adding new information is achieved by analysing each process step described in the IPPM. These process steps can be assumed to be non-value adding.

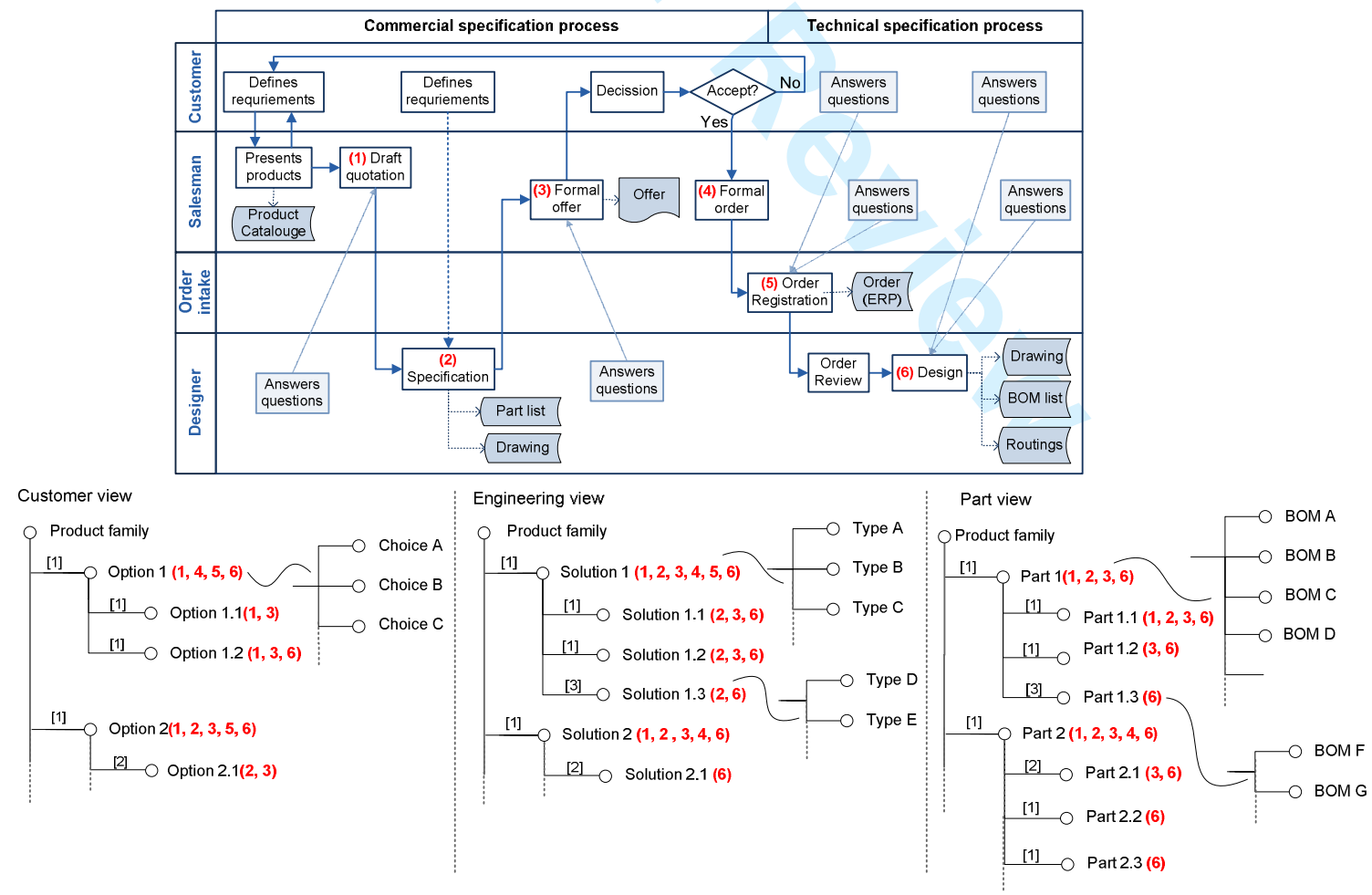

Figure 2: The IPPM. 
The argument for choosing the 'number system' is that from a visual perspective it is recognised as being the most effective thus avoiding the model becoming confusing to look at and clearly highlighting repeated information entries.

Modelling how the product information is processed will make it possible to eliminate mismatched and missing information and enable a more efficient use of product configuration systems and other IT systems to support the process. In the modelling process questions may be asked such as: Do we have a full specification as early as possible in the process sequence? How many times do we deal with the same product feature in different process steps? Which product features are needed in each step? Which qualifications and information are needed for the actors in each step to decide upon the product features in question? Is it possible to work in parallel? How often is the information passed between actors? How many information systems are used in the process? How often is the information manually re-entered between different systems?

It is suggested that an adjusted version of VSM is used with the IPPM to communicate the process performance in quantifiable terms. The VSM helps to identify potential process improvements (including minimizing waiting times between activities) for the end-to-end business process, across process steps and organizational boundaries, but the information communicated by the IPPM is an important enabler to identify non-value adding activities. A suggestion of how the traditional VSM can be adjusted to map the specification process is presented in Figure 3.

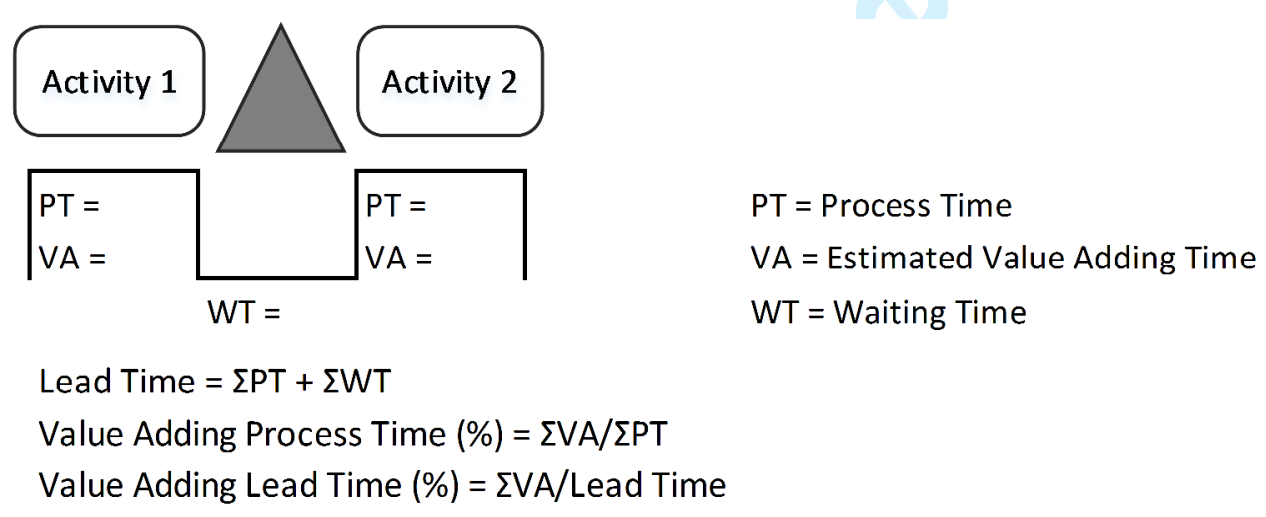

Figure 3: An approach to VSM of the specification process.

Each activity in the business process is presented with an activity box, and the buffers between the activities are presented with triangles (corresponding to buffers in the traditional VSM). For each activity the Process Time 
(PT) (the time duration of how long it takes to perform an activity, from when the activity is started until it is finalized) and estimated Value Adding Time (VA) (the time duration required for completing an activity if only value adding activates were included) are determined. The buffers document the Waiting Times (WT) that is, the time when the information is waiting to be processed. Waiting times are never value adding, and should thus be minimized. This can be done through, for example, better planning, minimizing batch sizes and running processes in parallel. More specifically, better planning could, for example, be in the form of assigning more human resources to tasks that produce waiting times, while reducing resources assigned to tasks that do not produce waiting times; reducing batch sizes, among other things, means that each batch makes it through the full lifecycle quicker, implying shorter waits for feedback about if batches have been produced correctly; and running tasks in parallel implies having a focus on designing and producing various subsystems simultaneously, as opposed to waiting for the design/production of one subsystem to be complete before initiating the next.

The performance of the specification process is evaluated by the Lead Time (LT) of the entire business process (calculated by the sum of the cumulative PT and the cumulative WT) and by the percentage of time that is considered value adding. In this case the LT presents the expected time duration of the specification process, starting when a salesman initiates the activity of making a draft quotation for the customer and concluding when the production starts. The rate of the process that is value adding, is calculated from two perspectives; first the rate of Value Adding Processing Time, is the percentage of process time that is used on value adding activities and second the rate of Value Adding Lead Time, is the percentage of the process lead time that is used for value adding activities. For example, if the cumulative PT is 8,15 hours, the cumulative WT is 1,85 hours, and the percentage of process time that is used on value adding activities is $80 \%$, the time reduction potential is 1,85 hours $+8,15$ hours $*(100 \%-80 \%) / 100 \%=3,48$ hours. Although, it may not be feasible to achieve the full time reduction potential, knowing these kinds of numbers provides directions as for where to focus, i.e. where the greatest potentials for time reductions are.

\section{Research method}


To address the research questions stated in the introduction, three case studies were carried out. The first case study aimed at acquiring a deeper understanding of the application of the proposed approach, while the latter two had the aim of investigating if the results from the first case could also be obtained in other cases. Thus, the first case was more thoroughly investigated, and the use of the approach is only described for the first case, while the two other cases are only used for evaluative purposes.

The first case company is a global provider of advanced equipment and systems for the food processing industry. The second study is of a company that makes engines for ships and power plants, while the third study company is in the construction business. The effectiveness of using the approach was evaluated by three semistructured interviews carried out with engineers who had applied the proposed approach. These interviews each lasted around 1 hour. In total five engineers were interviewed. Three from the first company, and one from the second and the third company each.

\section{Case studies}

The first case study, as mentioned, involved a global provider of advanced equipment and systems for the food processing industry. The company has about 4,000 employees. The company's portfolio includes $8-10$ product families of varying complexities. As an example of how to include product features in the process redesign, a representative product family, conveyors, were modelled together with the process flow. The conveyors are a part of the total production line provided and, like the other machines, are designed/adapted for each individual project. The conveyors were also chosen because of their order frequency; the conveyors are included in almost every project conducted by the company and it is estimated that around 600 conveyors are designed each year.

At the time of the research both the company and the product portfolio had been growing at a fast pace. Business processes had evolved casually, and processes were often undefined. The high level of product complexity made the transaction of information regarding product designs difficult. Misunderstandings and missing information frequently introduced interruptions in the specification processes, and wrong, incomplete or delayed specifications led to errors in production. 


\subsection{The ASIS Model}

\subsubsection{The ASIS product model}

Before this project, the company did not have any product models to visualise the structure of the product family of conveyors. Knowledge regarding the product design, for example design guidelines and price calculations were found in spreadsheets, CAD drawings, in the ERP (Enterprise Resource Planning) system and from employees. Every conveyor includes four parts: a frame, a belt, a conveyor end module and a motor. The most important design parameters are the height, width and length of the frame. Furthermore, conveyors often turn or rise in gradient. The belts can be of various types and made of different materials. It is possible to add options to the standard structure such as flights, side guard belt washers, in-end-covers etc. A PVM of the ASIS structure of the conveyors and its corresponding process model is shown in Figure 4.

\subsubsection{The ASIS specification process}

The products are sold through an extensive global sales network that spans more than forty countries. Sales and Service Units (SSUs) employ salesmen and are responsible for servicing customers in each of the local areas. The communication between the sales offices and engineering and production goes through the Order Handling Unit (OHU).

The salesmen are equipped with a quotation spreadsheet. In the spreadsheet the conveyors are defined in different contexts, for example, as accessories, as in-feeds and out-feeds, as accelerators, as standard conveyors between predefined machines and as specialised conveyors. If the customer and the salesmen are not able to work out a solution using the spreadsheet, the salesman contacts a technical sales assistant to draw out a more detailed solution. This activity might include several loops and handovers. When an acceptable solution has been found, the technical sales assistant calculates the price using the spreadsheet and prepares a formal offer for the customer.

If the customer accepts the offer, the salesman fills in the offer template and sends it to the customer. The sales opportunity is changed into a sale in the ERP-system, the required sales documents are created, and finally the order is mailed to the SSU. The SSU office registers the order in their local database and forwards it to the 
OHU. The OHU registers the order in the central database and then sends an order confirmation to the customer. Finally, a project manager is assigned to the project and a project team is created. At the design stage, designers frequently need to contact the salesmen to get additional information such as the layout of the factory housing. The production is initiated when the specifications are complete.

\subsubsection{Integrating the ASIS process and the product model}

The ASIS process map and the product model (PVM) are outlined in Figure 4. The insights obtained from working out the two models simultaneously are outlined in Table 1. 


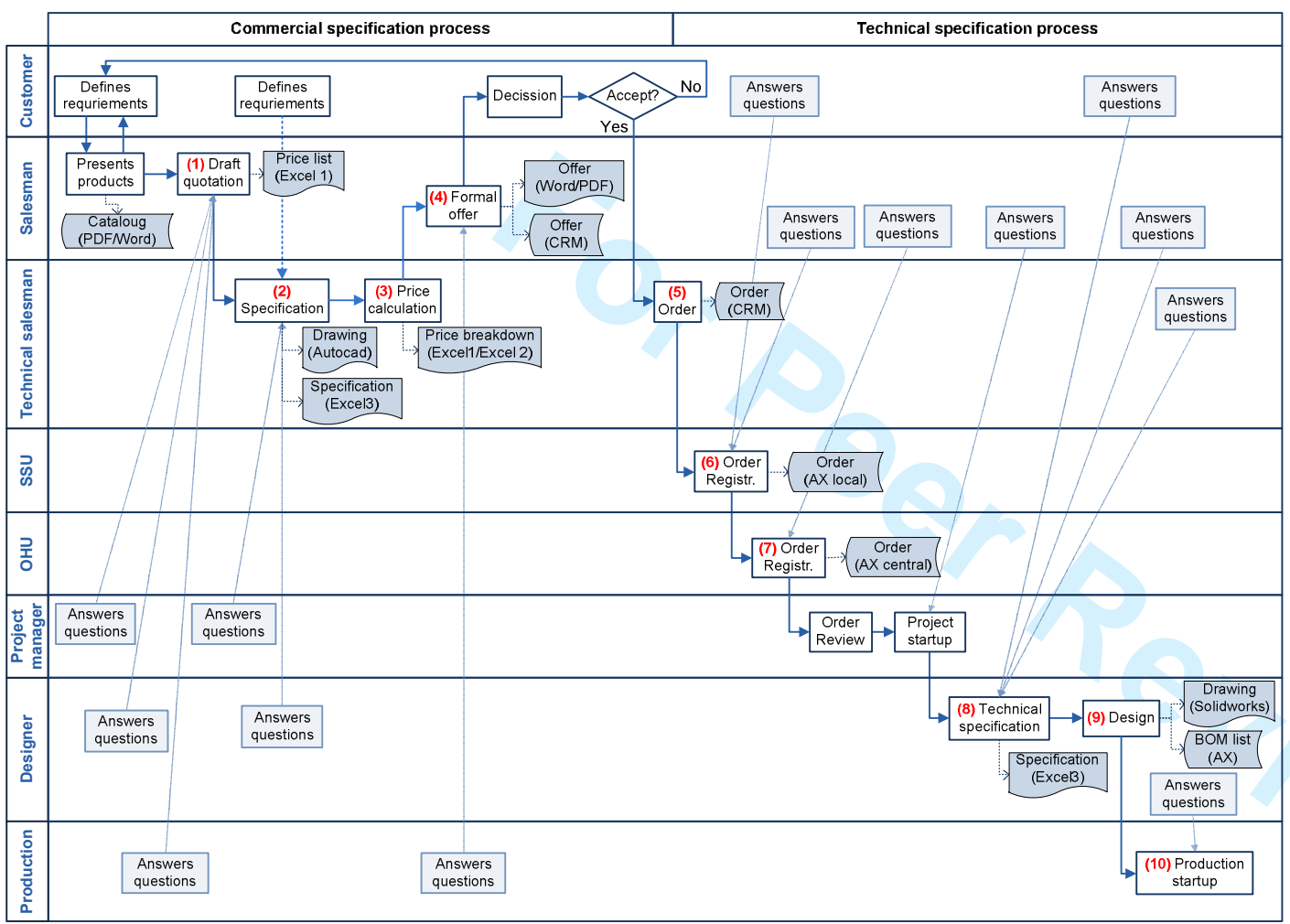

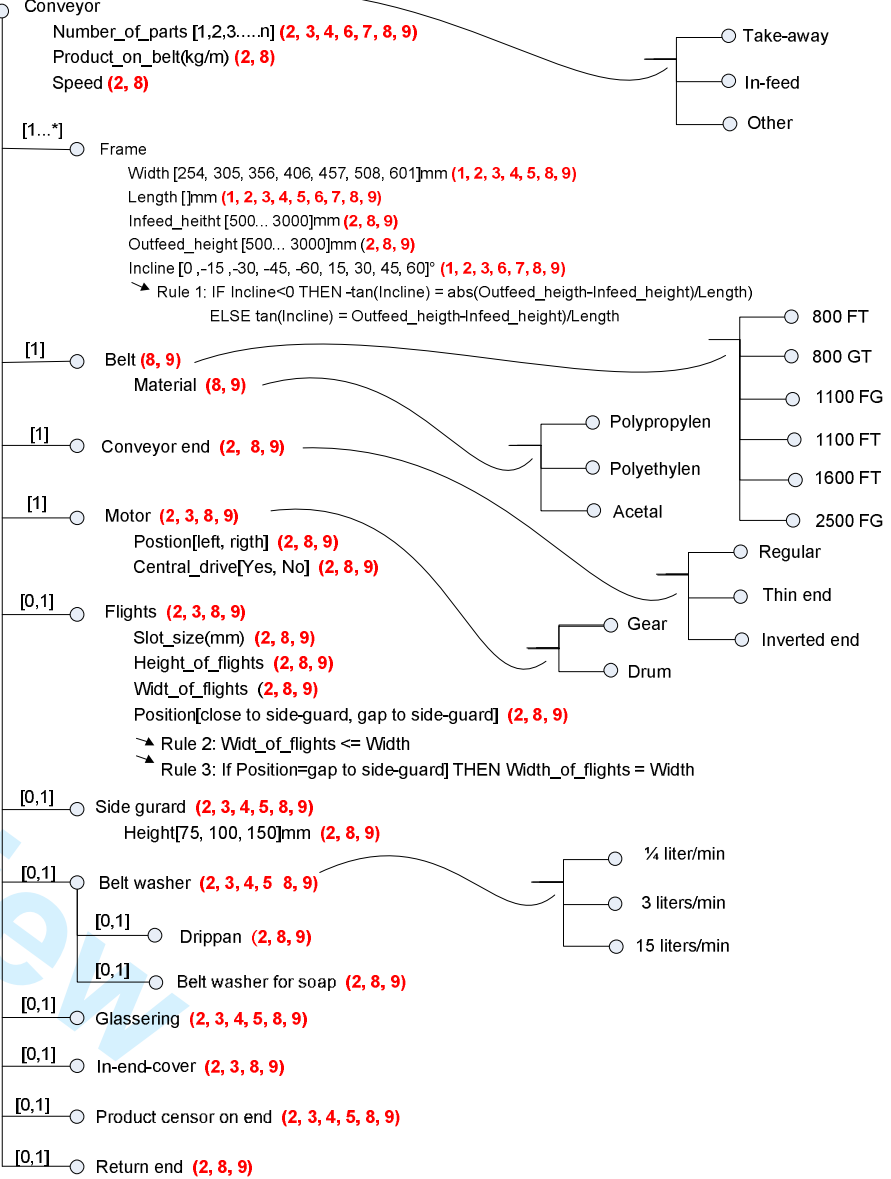

Figure 4: The IPPM for the ASIS specification process of conveyors. 
Table 1: Insights obtained from the ASIS IPPM

\begin{tabular}{|c|c|}
\hline Issue & Explanation \\
\hline $\begin{array}{l}\text { Product features only } \\
\text { presented in one view }\end{array}$ & $\begin{array}{l}\text { Although the product is represented in different level of detail in the various } \\
\text { specifications, the specifications only present the product features in the same } \\
\text { view, i.e. the part view. The product features are simplified for the sales office by } \\
\text { reducing the level of detail (see features marked with } 1 \text { and } 4 \text { ), but they do not } \\
\text { transfer the information to features that the customer can specify or enable him to } \\
\text { express his needs. In other words, the technical knowhow has not been transferred } \\
\text { to the sales office. The next } 3 \text { Issues are a result of this. }\end{array}$ \\
\hline $\begin{array}{l}\text { Sales process leaves } \\
\text { out important } \\
\text { information }\end{array}$ & $\begin{array}{l}\text { The sales meeting is the prime opportunity to capture the customer requirements. } \\
\text { The spreadsheets used in the sales process leaves out, important information, } \\
\text { such as the shape and texture of the product (e.g. frozen, fresh or sticky), the } \\
\text { layout of the factory housing and the required throughput. Analysis of the } \\
\text { specifications reveals that this information is not included in any of the } \\
\text { specifications, but is required to make design decisions, such as the type of the } \\
\text { conveyor belt. This causes the technical office to re-contact the salesmen late in } \\
\text { the process. }\end{array}$ \\
\hline $\begin{array}{l}\text { Customers/salesmen } \\
\text { define information that } \\
\text { they don't have } \\
\text { technical knowledge of }\end{array}$ & $\begin{array}{l}\text { In the sales process the salesmen define structural features of the product (see } \\
\text { features marked with } 1 \text { and } 4 \text { ) of which they have only little knowledge and might } \\
\text { be difficult for the customers to define. Therefore they often contact a technical } \\
\text { sales assistant or provide uncomplete information. The information defined by the } \\
\text { salesmen has limited credability, sometimes causing the technical office to redefine } \\
\text { some already given features or re-contacting the salesmen. }\end{array}$ \\
\hline $\begin{array}{l}\text { Lack of detail from } \\
\text { sales process }\end{array}$ & $\begin{array}{l}\text { The only information that the salesmen are requested to specify during the meeting } \\
\text { and to make a draft quotation, is the width, length and incline of the conveyor (see } \\
\text { features marked with 1). This will give an unreliable price indication and is not } \\
\text { sufficient information for the technical salesman (in process step 2). }\end{array}$ \\
\hline $\begin{array}{l}\text { Resources for } \\
\text { manually making a } \\
\text { CAD drawing before a } \\
\text { order is placed }\end{array}$ & $\begin{array}{l}\text { Often a drawing is requested to communicate and discuss the solution with the } \\
\text { customer. This requires deciding on detailed structural design parameters and } \\
\text { using many resources for making CAD drawings (in process step 2), for offers that } \\
\text { may never turn into orders (in process step 5). }\end{array}$ \\
\hline Un-detailed quotation & $\begin{array}{l}\text { In order to make an exact quotation the parts included in the solution need to be } \\
\text { defined. Although these can be found from the CAD drawing (in process step 2), } \\
\text { the quotation spreadsheet (in process step 3) is less detailed and does not include } \\
\text { all the product features, such as the belt material, flights, side guards, motor type } \\
\text { etc. This can be seen by comparing the parts in the PVM marked with numbers } 2 \\
\text { and } 3 \text {. This affects the accuracy of the price calculation and results in unequal profit } \\
\text { margins. } \\
\text { If the salesman does not contact the technical salesman, the order and the } \\
\text { quotation information become even less detailed (see features marked with } 1 \text { and } \\
\text { 4). Furthermore none of the ordering sheets prompt the users to define all the } \\
\text { required information. The salesmen can therefore submit orders without completing } \\
\text { the Excel sheet. }\end{array}$ \\
\hline $\begin{array}{l}\text { Several un-integrated } \\
\text { IT systems }\end{array}$ & $\begin{array}{l}\text { Several software systems are used in the process. Since the software systems } \\
\text { have not been integrated, it becomes necessary to re-enter product features and } \\
\text { order information, for example when registering the order to the ERP system. This } \\
\text { can be seen from the IT tools named under the output documents listed at the } \\
\text { different process steps. }\end{array}$ \\
\hline $\begin{array}{l}\text { Product features } \\
\text { documented several } \\
\text { times }\end{array}$ & $\begin{array}{l}\text { Some information like the length of the product is specified in up to } 9 \text { process steps } \\
\text { by at least } 5 \text { different actors. This presents the risk of typos, likely resulting directly } \\
\text { in the customer receiving the wrong order. From the IPPM it can be seen that all } \\
\text { the information specified in process steps } 6,7 \text { and } 8 \text { has already been specified in } \\
\text { previous process steps. }\end{array}$ \\
\hline $\begin{array}{l}\text { Product features } \\
\text { adjusted or re- } \\
\text { specified }\end{array}$ & $\begin{array}{l}\text { From the ASIS model it can be seen that although product features are defined } \\
\text { early in the process (process steps } 2 \text { and } 3 \text { ), they are often altered later in the } \\
\text { design process (process step 9) when the conveyor is designed in detail. }\end{array}$ \\
\hline
\end{tabular}




\subsubsection{The ASIS process performance}

The performance of the processes was mapped using the VSM modelling technique. The time duration for each activity was evaluated by interviewing the corresponding employees and by back tracking a sample of recent orders. This is considered to be a sufficiently accurate performance measurement for the purpose of this case. The value adding times were estimated by the authors in collaboration with the stakeholders, based on knowledge about the process e.g. identified by reviewing the IPPM and from knowledge of alternative solutions. More specifically, the employees participating had deep understandings of their products and processes, but had a hard time thinking in other ways of doing things. Thus, the job of the authors was to make them review existing processes and products more critically, as well as suggesting more efficient ways of carrying out processes, under the premise that anything other than the minimum amount of work absolutely essential is non-value adding. This, for example, includes reducing material movement distances, waiting times and the number of machine setup changes.

To simplify the analysis, an assumption is made that when an activity is started it can be carried out until it is finished. The PTs shown therefore present expected times for each activity given that everything works at it should. The ASIS VSM is demonstrated on Figure 5.

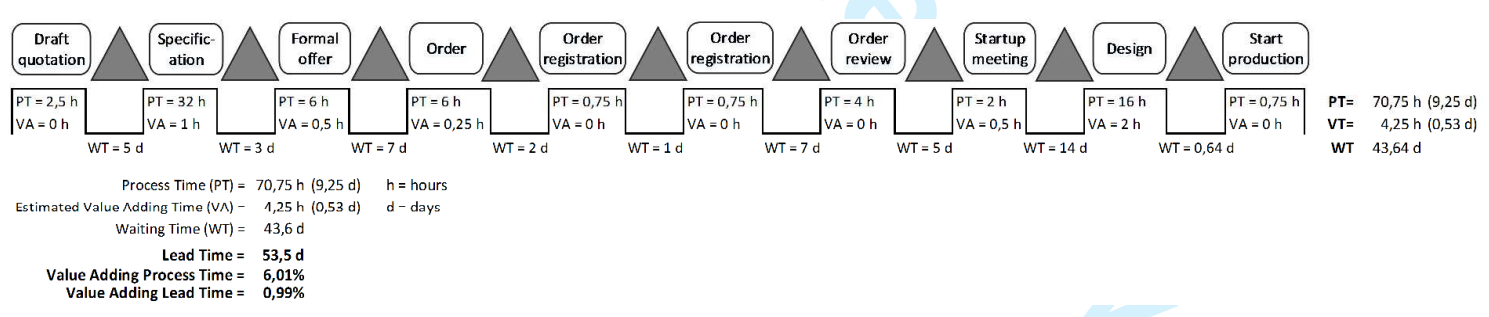

Figure 5: VSM of the ASIS specification process.

The VSM illustrated in Figure 5 shows that the lead time of the specification process is 53,5 days. A vast majority of the lead time, or 43,6 days, is waiting time between the main activities, while the cumulated processing time, where someone is working on the order, is 9,25 days.

The most significant opportunities for improvements are to be found in the activities with the longest waiting times or the biggest differences between the PT and the estimated VA time. The longest waiting time is in the technical specification process, before the design activity, where the conveyors are drawn in AutoCAD, caused by high workload at the design office. The processing time 
for making a drawing in process step 2, is the longest in the process, 4 working days. This time is especially costly as it directly extends the time until the customer receives an offer and since resources are used on making drawings for offers that might not turn into orders.

The VSM analysis shows that only about half a day is used for value-adding activities which is about $0,99 \%$ of the business process LT and $6,01 \%$ of the PT. From the IPPM it was noted that some process steps only involve re-entering already existing information. In addition an order review is required for each order. Better information management and automation could reduce the process time for these process steps, and they are therefore considered completely or partially, non-value adding. Three activities that are completely non-value adding are identified. The process times of the activities are not particularly long however, since they can be completely eliminated means that the corresponding waiting times would also be eliminated, introducing an opportunity for significant process improvements.

The time spent by the customer on reviewing the offer is included in the value stream. This might be out of the company's control. However, one may argue that better presented offers and a faster response to customer requests will increase the rate of accepted offers and possibly speed up the response time of the customer. In the current process, the expected waiting time for the customer receiving an order is about 12 days, which can be considered an un-effective service to the customer, who might not recall all the details of the sales meeting at this time.

When analyzing the work flow in this way, it furthermore becomes apparent that the average deviation of the duration of activities was high, especially if information is missing. Better information management (e.g. prompting users to define all required information) would reduce the time deviation making the process more simple and predictable.

As described in Figure 5, an assumption is made that it is possible to work on each activity from start to finish. In reality the employee carrying out the activity might be working on other activities simultaneously, or might need to request missing information, highly extending the time needed to finalize the activity. It was found that the time duration for each activity highly deviates between orders. This is not presented on the VSM. It could have been decided to present lead time for each activity, calculated as an average time duration. However, this would give a wrong impression, as a 
few very high values, would extend the time, out of proportion. In such cases, the median value would be a better choice. However, although using the median value, a skewed data distribution could still give a wrong impression. It could also have been possible to present a standard deviation, but not enough data was available to make a meaningful calculation.

\subsection{The TOBE model}

Including the PVM in the ASIS process analysis revealed that many product features are processed several times in the specification process sequence. This introduces the question of where the product features should be defined, by whom and how the process can be redesigned so that each product feature is only defined once. In order to accomplish these objectives it is necessary to redesign both the product model and the specification process.

\subsubsection{The TOBE product model}

The ASIS model in Figure 4 shows that the product features used in the specification process are neither adjusted to the activities nor to the actors. To improve this, the product model should be adjusted to the appropriate views of the product family (i.e. functional product features in the customer view and structural product features in the part view). Relationships can then be established between the views to automate the information transformation. The PVM was restructured in cooperation with experienced salesmen and designers.

A part of the redesigned product model is shown in the PVM in Figure 6. The different views of the PVM and the causal relationships between the three views help to define the input and output of a configuration system and which product features need to be modified by a designer. The following section describes a suggested TOBE specification process, including how a configuration system might enable improvements in the TOBE specification process.

\subsubsection{The TOBE specification process}

The TOBE specification process is suggested to implement a product configuration system for automating some of the process steps in the specification process. The system will configure the physical dimensions of the conveyors based on the customers' input, and generate a drawing to 
improve the communication between the salesmen and the customers. A prototype version of the configuration system has been developed. The suggested configuration system will not be described further, as the focus is on the product and process modelling aspects.

Figure 6 shows how the salesman defines parameters marked with the number 1 on the PVM. Correspondingly, the configuration system configures the product features in the engineering and part view, marked with the number 2 on the PVM.

The ASIS IPPM model has revealed activities where information is only being re-entered. To improve the process efficiency, the IT systems across organisational boundaries need to be integrated. The configuration system should register orders automatically in the databases and ERP systems, see process step 7. In this way, activities such as creating an offer and registering the order are automated. This is important both to reduce human handling of information and to reduce the time when an order is waiting to be carried out, thus improving both speed and quality of the entire specification process.

\subsubsection{Integrating the TOBE process and product model}

The resulting suggested process and the use of information are shown in Figure 6. The figure shows the product features defined in the sales phase marked with (1) and product features processed by the configuration system, based on the input from the sales process marked with (2). Finally, product features that might be modified in the design phase are marked with (8). 
Table 2: Improvements in the TOBE process.

\begin{tabular}{|c|c|}
\hline Reduced data entries & $\begin{array}{l}\text { The model shows how the data entries in the specification process are reduced. Each } \\
\text { product feature is defined at most, two times by two actors. }\end{array}$ \\
\hline $\begin{array}{l}\text { Elimination of process } \\
\text { steps and handovers }\end{array}$ & $\begin{array}{l}\text { Several activities where information is being reentered, such as the order registration, } \\
\text { have now been eliminated. In this way, the complexity of the specification process is } \\
\text { reduced significantly, information handover is avoided and the likelihoods of errors are } \\
\text { reduced. }\end{array}$ \\
\hline $\begin{array}{l}\text { Capturing customer } \\
\text { requirements }\end{array}$ & $\begin{array}{l}\text { The salesman uses the configuration tool to present different solutions to the } \\
\text { customers. The product configuration is done in process step } 1 \text { by the salesman. Now } \\
\text { the salesman only specifies information about the product application (the customer } \\
\text { view). }\end{array}$ \\
\hline Precise quoations & $\begin{array}{l}\text { All the parts of the product have been identified by the configuration system in process } \\
\text { step } 2 \text { and are included in the price calculations, leading to more precise quotations. }\end{array}$ \\
\hline $\begin{array}{l}\text { Technical Know How } \\
\text { build in configuration } \\
\text { system }\end{array}$ & $\begin{array}{l}\text { Technical information about the product is now available in the configuration system, } \\
\text { and characteristics of the materials to be handled, is available to the designers. This } \\
\text { reduces the need of the salesmen for calling the technical office and the designers } \\
\text { contacting salesmen later in the process. }\end{array}$ \\
\hline
\end{tabular}

Figure 6: The IPPM for the TOBE specification process of conveyors.

Table 2 outlines the suggested improvements in the TOBE process.

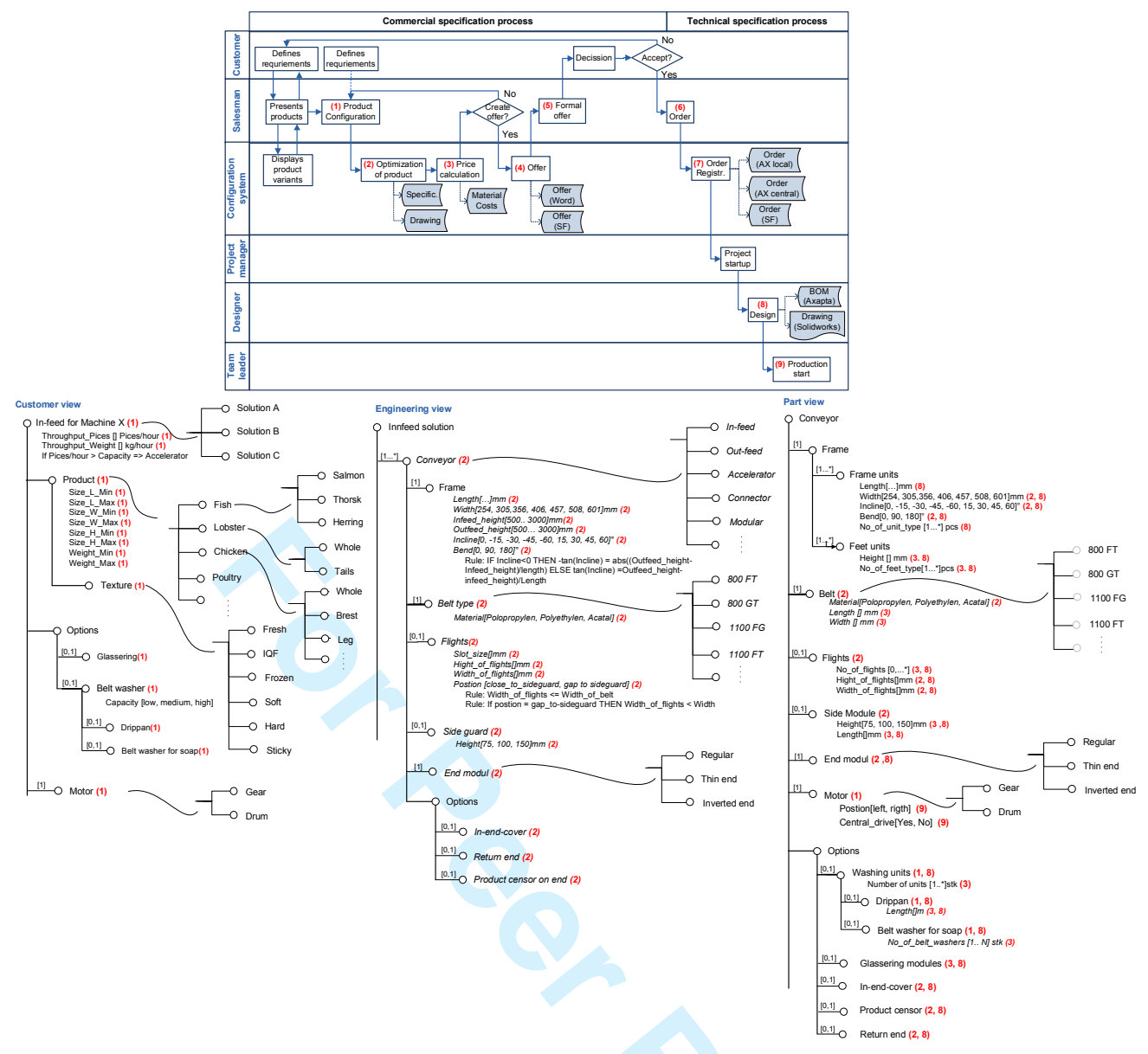




\subsubsection{The TOBE process performance}

To evaluate the estimated overall performance of the suggested TOBE specification process, a VSM for the TOBE process is outlined in Figure 7. The VSM highlights how a changed way of using product features and automating selected activities could speed up the specification process.

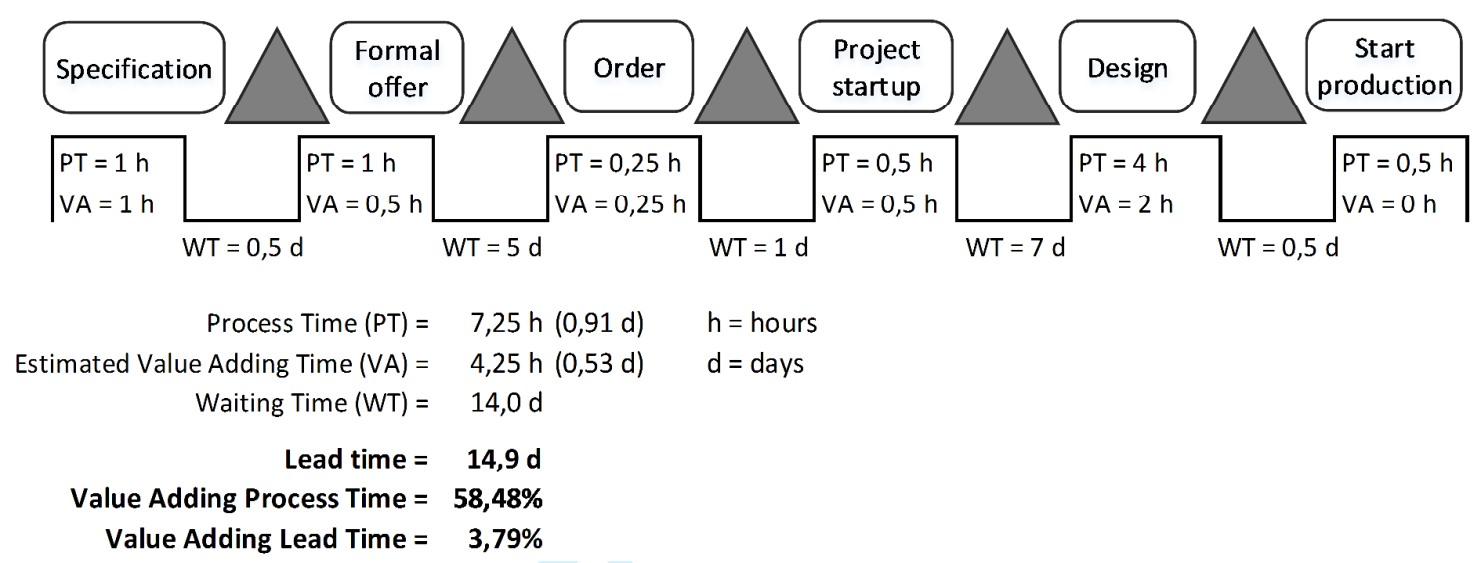

Figure 7: VSM for the TOBE specification process of conveyors.

The lead time of the process is reduced from 53,5 days to 14,9 days and the time for making an offer is reduced from approximately 2 weeks to one day. The salesmen can now present a formal offer within 5 hours of the sales meeting, which could be expected to increase the likelihood of closing the sale. The lead time from receiving an order to when the production can start has been reduced from 32 days to 12.5 days, which will directly affect the delivery time of the order.

The rate of Value Adding Process Time has increased to 58,48 \% (from 6,01\%) but the rate of Value Adding Lead Time is only 3,79\%. This is because, in this suggestion of the TOBE specification process, it is only the sales part of the process that has been supported with a configuration tool. Although this supports the technical specification process, e.g. by more correct information and fewer calls from the sales office, the activities in the technical process are still present including waiting times and in addition the waiting time for the customer is still estimated at 5 days.

The anticipated benefits for the company from implementing the TOBE specification processes were estimated based on interviews with three persons from sales, engineering and production who, based on their several years of experience, were able to make these estimates. The estimated benefits included:

- reduction of lead times, 
- reduction of resources for making specifications,

- Fewer process loops and interruptions because missing information, due to prompting the definition of required data,

- increased sales due to faster and more qualified quotations and delivery,

- increased quality of specifications leading to fewer errors,

- improved productivity in the production due to fewer errors,

- more accurate calculation of costs leading to increased gross margins of the projects partly due to the salesmen having more accurate pre-calculations, thus having a better basis for negotiating prices,

- adjusting the information to the customer and generating a drawing increases the likelihood that the selected product will best fit the intended purpose,

- engineering resources are freed up for product development instead of repetitive design work.

\subsection{Evaluation of the Proposed Technique}

To evaluate the IPPM modelling technique five engineers who had been working with the technique were interviewed: three engineers from the case described in the previous subsection, and two engineers from two other companies that had also applied the technique. The interviews focused on the applicability of the proposed technique. The summarised results of the interviews are listed in Table 3. 
Table 3: Evaluation of the IPPM modelling technique.

\begin{tabular}{|l|l|l|l|c|c|}
\cline { 2 - 5 } \multicolumn{1}{l|}{} & $\begin{array}{c}\text { Strongly } \\
\text { disagree }\end{array}$ & Disagree & Neutral & Agree & $\begin{array}{c}\text { Strongly } \\
\text { agree }\end{array}$ \\
\hline $\begin{array}{l}\text { In your opinion, would it be possible to identify and gather the } \\
\text { information needed by the company to document the IPPM? }\end{array}$ & & & & 3 & 2 \\
\hline $\begin{array}{l}\text { When you first saw the IPPM model, was it obvious to you } \\
\text { what information was being presented? }\end{array}$ & & & & 3 & 2 \\
\hline Were the purpose and the benefits of the IPPM model obvious? & & & 1 & 3 & 1 \\
\hline $\begin{array}{l}\text { Do you expect it will require little effort to learn to understand } \\
\text { the information on the IPPM model? }\end{array}$ & & 1 & 2 & 1 & 1 \\
\hline $\begin{array}{l}\text { Do you expect it will require little effort to learn to create an } \\
\text { IPPM model? }\end{array}$ & & 3 & 1 & 1 & \\
\hline $\begin{array}{l}\text { In your opinion, would the IPPM model be helpful to } \\
\text { communicate the specification process? }\end{array}$ & & & 5 & \\
\hline $\begin{array}{l}\text { In your opinion, would it be realistic to use this model by an } \\
\text { industrial company? }\end{array}$ & & & 1 & 4 & \\
\hline $\begin{array}{l}\text { In your opinion, would the information presented by the VSM of } \\
\text { the specification processes be valuable when evaluating the } \\
\text { investment of implementing a configuration tool? }\end{array}$ & & & 3 & 1 \\
\hline $\begin{array}{l}\text { In your opinion, would the information presented by the VSM of } \\
\text { the sales configuration process be valuable when evaluating the } \\
\text { optimal level of automation in a sales configuration process? }\end{array}$ & & & 1 & 4 & \\
\hline $\begin{array}{l}\text { In your opinion, would the IPPM model be useful for } \\
\text { redesigning the specification process? }\end{array}$ & & & & 4 & 1 \\
\hline $\begin{array}{l}\text { In your opinion, would the IPPM be useful to compare different } \\
\text { scenarios of a future (TOBE) specification process? }\end{array}$ & & & & 5 & \\
\hline $\begin{array}{l}\text { Do you think that the IPPM modeling technique could provide } \\
\text { additional insight into the specification processes relative to a } \\
\text { separate use of process mapping and PVM? }\end{array}$ & & & 4 & \\
\hline
\end{tabular}

As can be seen, the interviewees assessed that the IPPM and VSM would bring additional insights into the specification processes, and provide a basis for developing the specification processes including scenarios for possible use of product configuration systems. However, the engineers interviewed also anticipated that it would require resources to learn to create the models.

Although the model provides valuable input it still lacks some expressive abilities. The IPPM currently only shows where information is being entered or documented. However, often information is used in a process step although it is not entered. An overview of which information is needed in each process step would be valuable and is currently missing.

When analysing the specification process, it was identified that specific information was supposed to be filled in during certain process steps. However, it was possible to carry on without filling in all the information. This is important since missing information can cause serious problems later on in the process. Identifying which information is prompted in each process step, and implementing tools that prevent the actors from submitting incomplete data sheets is an important step to avoid errors and process loops. 


\section{Discussion of results}

\subsection{Comparison with other modelling techniques}

The aim of the presented modelling technique is to provide a visual overview and insight into the endto-end specification process. An important aspect therefore, is that it utilises existing modelling techniques that communicate and visualize process flows and product features used. The BPMN notation includes pools or lanes. This enables structuring the process according to its participants, clearly distinguishing their responsibilities and retaining a clear layout even in the case of a complex process structure. This is an important feature of BPMN, compared to other models such as EPC and IDEF0.

Another aspect of the BPMN is that it is quite compact and it can therefore be possible to present a sufficient overview of the process in one map. The IDEF0 for example suggests a layered model, however, presenting the model in many separate parts reduces the visual overview. The BPMN and the UML activity diagrams have similar capabilities; here the BPMN is selected simply as it tends to be favoured for the application of business process analysis while the UML activity diagram is preferred for software development. The shortcomings of the BPMN are that it does not communicate milestones and the duration of process steps. For this reason the VSM was included.

The VSM was selected as the explicit demonstration of waiting times and non-value-adding activities are powerful tools to communicate process improvement opportunities. Another modelling technique that shows time duration visually is Gantt chart notation, which could also be applied for showing time dependencies. The VSM has been chosen here as it is closely related to the process model.

When comparing PVM with UML class diagrams, UML is used for modelling IT systems, and has to follow the rigorous principles of object-oriented modelling. The PVM may be seen as an adaption of UML to model products, as the PVM has 'kind of' and 'part of' structures corresponding to aggregation and generalisation structures in UML, but the notation is less formal, and it is possible to add pictures, tables etc. to the PVM. 
The use of the IPPM and the VSM are related in the way that it would be difficult to establish the value/non-value adding times without the information provided by the IPPM model, because the nonvalue adding activities are mainly a result of inefficiencies in how product data is processed.

The way of linking the models is furthermore important, as it should highlight the problems in the process as effectively as possible. Compared with the matrix based methods of Reinhart et al. (2014) and Nilsson and Fagerström (2003) the method presented here is more visually expressive. The method of listing the process steps where the features are specified, gives an immediate overview of possible process insufficiencies including features, which are repetitively entered. Using the method presented by Hogrebe et al. (2009) it would be more difficult to find and compare the repeated attributes. Finally compared to the other methods for integrating the models, the numbering method is less space consuming and can be expected to be more easily expandable to include more process steps or product features.

\subsection{Discussion of generalizability}

The studies of the three cases showed that the proposed method worked in the sense that it was possible to integrate the modelling of processes and products in the way the method prescribed. In this context it was important that none of the three companies studied were niche players, on the contrary, they had similar characteristics to many other suppliers of customised industrial machinery. It should further be noted that the specification processes and product range analysed had many similarities with other industry companies. Furthermore, these types of companies have previously applied both BPMN and PVM modelling techniques for modelling processes and products respectively (Forza and Salvador, 2007; Hvam, 2008). Since the related modelling techniques are generally applicable in these kinds of companies, there seems to be a general trait of these in relation to their use. Such aspects also support the generalizability of the usefulness of the proposed method.

\section{Conclusions}

This paper proposed a visual modelling method for integrating models of product features with business process models for redesigning the business processes involving specification of customer 
tailored products and services. The method was developed based on the literature. Five engineers in three companies that had worked with the technique evaluated the method, and all found it very useful.

Referring to the research questions posed in the introduction, the case studies revealed that it is possible to model the features being defined in each step of the specification processes, with sufficient visibility to gain insight into how product features are processed. The suggested IPPM modelling technique integrating the PVM and process mapping offered valuable insights into how the product features are processed in each step of the process flow. More specifically, the link between the PVM and the process model gave a deeper understanding of the specific activities in the process flow. It also highlighted the usefulness of the PVM as a modelling technique including the use of the three views (customer, engineering and production).

The VSM proved to be useful to identify the lead time of the specification process and to evaluate the resources and time spent at each step of the specification process. The VSM identified significant waiting times both between and within the activities and revealed that by redefining the use of product features and automating some of the information processing significant process improvements could be enabled.

The modelling has been carried out in Microsoft Visio and no evaluation of other tools that can possibly be used for the modelling has been done. However the idea here is rather to present the modelling technique as such. For future research it would also be interesting to build the information from the IPPM and VSM into an operational simulation model, including deviations in processing times, to get a more accurate identification of the performance and issues in the specification process and how specific improvements affect its performance. Finally, the integrated use of the PVM and process mapping could also be used as a tool for a coordinated redesign of both the product family and for example, the specification processes.

\section{References}

Andreasen, M.M. (1994). Modelling: The language of the designer, Journal of Engineering Design, 5(2): 103-115. 
Anumba, C.J., Baldwin, A.N., Bouchlaghem, D., Prasad, B., Cutting-Decelle, A.F., Dufau, J. and Mommessin, M. (2000). Integrating concurrent engineering concepts in a steelwork construction project, Concurrent Engineering, 8(3): 199-212.

Barber, C.S. and Tietje, B.C. (2008). A research agenda for value stream mapping the sales process, Journal of Personal Selling and Sales Management, 28(2): 155-165.

Biazzo, S. (2000). Approaches to business process analysis: a review, Business Process Management Journal, 6(2): 99-112.

Booch, G., Rumbaugh, J. and Jacobson I. (1999). The Unified Modeling Language User Guide, Addison-Wesley, Upper Saddle River, NJ

BPMI.org, (2011). Business Process Modeling Notation (BPMN), Version 2.0, available at: www.bpmi.org (Accessed 20 April 2015).

Browning, T.R. and Ramasesh, R.V. (2007). A Survey of Activity Network-Based Process Models for Managing Product Development Projects, Production and Operations Management, 16(2): 217240.

Burgess, T.F., McKee, D. and Kidd, C. (2005). Configuration management in the aerospace industry: a review of industry practice, International Journal of Operations \& Production Management, 25(3): 290-301.

Chan, S.F.C., Dillon, T. and Ng, V.T.Y (2003). Exchanging STEP data through XML-based mediators, Concurrent Engineering: Research and Applications, 11(1): 55-64.

Damij, N. (2007). Business process modelling using diagrammatic and tabular techniques, Business Process Management Journal, 13(1): 70-90.

Forza, A. and Salvador, F. (2008). Application support to product variety management, International Journal of Production Research, 46(3): 817-836.

Forza, C. and Salvador, F. (2007). Product Information Management for Mass Customization: Connecting Customer, Front-office and Back-office for Fast and Efficient Customization, Palgrave Macmillan, New York, NY. 
Grover, V. and Malhotra, M.K. (1997). Business process reengineering: A tutorial on the concept, evolution, method, technology and application, Journal of Operations Management, 15(3): 193213.

Harlou, U. (2006). Developing Product Families Based on Architectures, Doctoral dissertation, Department of Mechanical Engineering, Technical University of Denmark.

Houser, J.R. and Clausing, D. (1988). The house of quality, Harvard Business Review, 66(3): 63-73.

Holweg, M. (2005). The three dimensions of responsiveness, International Journal of Operations \& Production Management, 25(7): 603-622.

Hogrebe, F., Nüttgens, M., Kern, H. and Kühne, S. (2009). Towards an Integrated Product and Process Modelling: oEPC Markup Language (oEPML) for object-oriented Event-driven Process Chains (oEPC), GI Jahrestagung, pp. 3364-3377.

Hopp, W.J., Iravani, S.M. and Liu, F. (2009). Managing white-collar work: An operations-oriented survey, Production and Operations Management, 18(1): 1-32.

Hubka V. (1988). Theory of Technical Systems, Springer, Heidelberg.

Hvam, Lars (2001). A Procedure for the Application of Product Modelling; International Journal of Production Research, vol. 39, No. 5, p. 873-885. ISSN 0020-7543

Hvam, L., Mortensen, N.H. and Riis, J. (2008). Product Customization, Springer, Heidelberg.

Hvam, L., Haug, A., Mortensen, N. H., \& Thuesen, C. (2013). Observed benefits from product configuration systems. International Journal of Industrial Engineering: Theory, Applications and Practice, 20(5-6).

Jiao, J., Tseng, M., Ma, Q., Yi, Z., 2000. Generic bill-of-materials and-

operations for high-variety production management, Concurrent Engineering: Research and Applications, 8(4): 297-321.

Khan, R. N. (2004). Business Process Management-A Practical Guide, Meghan, Tampa, FL.

Kimmance, A.G., Anumba, C.J., Bouchlaghem, D.M. and Baldwin, A.N. (2004). The application of information modelling methodologies: The HIPPY approach to integrated project modelling, International journal of computer applications in technology, 20(1): 62-77.

Klotz, L., Horman, M., Bi, H.H. and Bechtel, J. (2008). The impact of process mapping on transparency, International Journal of Productivity and Performance Management, 57(8): 623-636. 
Ko, R.K.L., Lee, S.S.G. and Lee, E.W. (2009). Business process management (BPM) standards: a survey, Business Process Management Journal, 15(5): 744-791.

Kritchanchai, D. and MacCarthy, B.L. (1999). Responsiveness of the order fulfilment process. International Journal of Operations \& Production Management, 19(8): 812-833.

Lasa, I.S., Laburu, C.O. and Vila, R.C. (2008). An evaluation of the value stream mapping tool, Business Process Management Journal, 14(1): 39-52.

Lawson, M. and Karandikar, H.M. (1994). A survey of concurrent engineering, Concurrent Engineering: Research and Applications, 2(1): 1-6.

Leibrecht, S., Van, T.N.P. and Anderl, R. (2004). Techniques for the integration of expert knowledge into the development of environmentally sound products, Journal of engineering design, 15(4): 353-366.

Lovelle, J. (2001). Mapping the value stream, IIE solutions, 33(2): 26-32.

Li, G. and Rajagopalan, S. (2008). Process Improvement, Learning and Real Options, Production and Operations Management, 17(1): 61-74.

Lu, R.F., Petersen, T.D. and Storch, R.L. (2007). Modeling customized product configuration in large assembly manufacturing with supply-chain considerations, International journal of flexible manufacturing systems, 19(4): 685-712.

Luh, D.-B., Ko, Y.-T. and Ma, C.-H. (2011). A structural matrix-based modelling for designing product variety, Journal of Engineering Design, 22(1): 1-29.

McManus, H. (2004). Product Development Value Stream Mapping Manual, Beta version ed., MIT Lean Aerospace Initiative, Cambridge, MA.

Mortensen, N. H. et.al. (2011).Making Product Customization Profitable: International Journal of Industrial Engineering, vol17. issue 1, p. 25-35, 2010.Nash, M.A. and Poling, S.A. (2009). Process mapping for the 21st century quality, Quality Magazine, 48(8): 24-25.

Nilsson, P. and Fagerström, B. (2003). Integrated product and process modelling, ASME 2003 International Design Engineering Technical Conferences and Computers and Information in Engineering Conference, Chicago, IL, September 2-6, 2003, pp. 603-612. 
Prasad, B. (1996). Concurrent Engineering Fundamentals: Integrated product and process organization, Prentice Hall PTR, Upper Saddle River, N.J.

Prasad, B. 2016). On mapping tasks during product development, Concurrent Engineering: Research and Applications, 24(2): 105-112.

Recker, J., Indulska, M., Rosemann, M. and Green, P., (2005). Do Process modeling techniques get better? A comparative ontological analysis of BPMM, 16th Australasian Conference on Information Systems, Sydney.

Reinhart, G., Kurfer, J., Westermeier, M. and Zeilinger, T. (2014). Integrated product and process model for production system design and quality assurance for EV battery cells, Advanced Materials Research, 907(1): 365-378.

Rosemann, M., Green, P., Indulska, M. and Recker, J. (2009). Using ontology for the representational analysis of process modeling techniques, International Journal of Business Process Integration and Management, 4(4): 251-265.

Rother, M. and Shook, J. (1998). Learning to See: Value Stream Mapping to Add Value and Eliminate Muda, Lean Enterprise Institute, Brookline, MA.

Schwarze S. (1996). Configuration of Multiple-Variant Products, BWI, Zürich.

Schulze, A., Schmitt, P., Heinzen, M. Mayrl, P., Heller, D. and Boutellier, R. (2013). Exploring the 4I framework of organisational learning in product development: Value stream mapping as a facilitator, International Journal of Computer Integrated Manufacturing, 26(12): 1136-1150.

Skyttner, L. (2005). General Systems Theory, World Scientific, Singapore.

Stumpf, A. L., Ganeshan, R., Chin, S. and Liu, L.Y. (1996). Object-oriented model for integrating construction product and process information, Journal of Computing in Civil Engineering, 10(3): 204-212.

Suh, N.P. (1998). Axiomatic design theory for systems, Research in engineering design, 10(4): 189209.

Tenhiälä, A. and Ketokivi, M. (2012). Order management in the customization-responsiveness squeeze, Decision Sciences, 43(1): 173-206. 
Tyagi, S., Choudhary, A., Cai, X. and Yang, K. (2015). Value stream mapping to reduce the lead-time of a product development process, International Journal of Production Economics, 160(1): 202212.

Tönshoff, H.K. and Zwick, M. (1998). An Integrated product and process model, Globalization of Manufacturing in the Digital Communications Era of the 21st Century: Innovation, Agility and the Virtual Enterprise: Proceedings of the Tenth International IFIP WG5. 2/5.3 International Conference PROLAMAT 98, Trento, Italy, p. 209.

White, S.A. (2004). Introduction to BPMN, BPTrends, available at: www.bptrends.com/publicationfiles/07-04\%20WP\%20Intro\%20to\%20BPMN\%20-\%20White.pdf (Accessed 30 April 2015).

Yang, W.Z., Xie, S.Q., Ai, Q.S. and Zhou, Z.D. (2008). Recent development on product modeling: A review, International Journal of Production Research, 46(21): 6055-6085.

Zhang, L.L., Lee, C.K. and Xu,Q. (2010). Towards product customization: An integrated order fulfillment system, Computers in Industry, 61(3): 213-222. 


\section{Including Product Features in Process Redesign}


Table 1: Insights obtained from the ASIS IPPM

\begin{tabular}{|c|c|}
\hline Issue & Explanation \\
\hline $\begin{array}{l}\text { Product features only } \\
\text { presented in one view }\end{array}$ & $\begin{array}{l}\text { Although the product is represented in different level of detail in the various } \\
\text { specifications, the specifications only present the product features in the same } \\
\text { view, i.e. the part view. The product features are simplified for the sales office by } \\
\text { reducing the level of detail (see features marked with } 1 \text { and } 4 \text { ), but they do not } \\
\text { transfer the information to features that the customer can specify or enable him to } \\
\text { express his needs. In other words, the technical knowhow has not been transferred } \\
\text { to the sales office. The next } 3 \text { Issues are a result of this. }\end{array}$ \\
\hline $\begin{array}{l}\text { Sales process leaves } \\
\text { out important } \\
\text { information }\end{array}$ & $\begin{array}{l}\text { The sales meeting is the prime opportunity to capture the customer requirements. } \\
\text { The spreadsheets used in the sales process leaves out, important information, } \\
\text { such as the shape and texture of the product (e.g. frozen, fresh or sticky), the } \\
\text { layout of the factory housing and the required throughput. Analysis of the } \\
\text { specifications reveals that this information is not included in any of the } \\
\text { specifications, but is required to make design decisions, such as the type of the } \\
\text { conveyor belt. This causes the technical office to re-contact the salesmen late in } \\
\text { the process. }\end{array}$ \\
\hline $\begin{array}{l}\text { Customers/salesmen } \\
\text { define information that } \\
\text { they don't have } \\
\text { technical knowledge of }\end{array}$ & $\begin{array}{l}\text { In the sales process the salesmen define structural features of the product (see } \\
\text { features marked with } 1 \text { and } 4 \text { ) of which they have only little knowledge and might } \\
\text { be difficult for the customers to define. Therefore they often contact a technical } \\
\text { sales assistant or provide uncomplete information. The information defined by the } \\
\text { salesmen has limited credability, sometimes causing the technical office to redefine } \\
\text { some already given features or re-contacting the salesmen. }\end{array}$ \\
\hline $\begin{array}{l}\text { Lack of detail from } \\
\text { sales process }\end{array}$ & $\begin{array}{l}\text { The only information that the salesmen are requested to specify during the meeting } \\
\text { and to make a draft quotation, is the width, length and incline of the conveyor (see } \\
\text { features marked with 1). This will give an unreliable price indication and is not } \\
\text { sufficient information for the technical salesman (in process step 2). }\end{array}$ \\
\hline $\begin{array}{l}\text { Resources for } \\
\text { manually making a } \\
\text { CAD drawing before a } \\
\text { order is placed }\end{array}$ & $\begin{array}{l}\text { Often a drawing is requested to communicate and discuss the solution with the } \\
\text { customer. This requires deciding on detailed structural design parameters and } \\
\text { using many resources for making CAD drawings (in process step 2), for offers that } \\
\text { may never turn into orders (in process step 5). }\end{array}$ \\
\hline Un-detailed quotation & $\begin{array}{l}\text { In order to make an exact quotation the parts included in the solution need to be } \\
\text { defined. Although these can be found from the CAD drawing (in process step 2), } \\
\text { the quotation spreadsheet (in process step 3) is less detailed and does not include } \\
\text { all the product features, such as the belt material, flights, side guards, motor type } \\
\text { etc. This can be seen by comparing the parts in the PVM marked with numbers } 2 \\
\text { and } 3 \text {. This affects the accuracy of the price calculation and results in unequal profit } \\
\text { margins. } \\
\text { If the salesman does not contact the technical salesman, the order and the } \\
\text { quotation information become even less detailed (see features marked with } 1 \text { and } \\
\text { 4). Furthermore none of the ordering sheets prompt the users to define all the } \\
\text { required information. The salesmen can therefore submit orders without completing } \\
\text { the Excel sheet. }\end{array}$ \\
\hline $\begin{array}{l}\text { Several un-integrated } \\
\text { IT systems }\end{array}$ & $\begin{array}{l}\text { Several software systems are used in the process. Since the software systems } \\
\text { have not been integrated, it becomes necessary to re-enter product features and } \\
\text { order information, for example when registering the order to the ERP system. This } \\
\text { can be seen from the IT tools named under the output documents listed at the } \\
\text { different process steps. }\end{array}$ \\
\hline $\begin{array}{l}\text { Product features } \\
\text { documented several } \\
\text { times }\end{array}$ & $\begin{array}{l}\text { Some information like the length of the product is specified in up to } 9 \text { process steps } \\
\text { by at least } 5 \text { different actors. This presents the risk of typos, likely resulting directly } \\
\text { in the customer receiving the wrong order. From the IPPM it can be seen that all } \\
\text { the information specified in process steps } 6,7 \text { and } 8 \text { has already been specified in } \\
\text { previous process steps. }\end{array}$ \\
\hline $\begin{array}{l}\text { Product features } \\
\text { adjusted or re- } \\
\text { specified }\end{array}$ & $\begin{array}{l}\text { From the ASIS model it can be seen that although product features are defined } \\
\text { early in the process (process steps } 2 \text { and } 3 \text { ), they are often altered later in the } \\
\text { design process (process step 9) when the conveyor is designed in detail. }\end{array}$ \\
\hline
\end{tabular}


Table 2: Improvements in the TOBE process.

\begin{tabular}{|c|l|}
\hline Reduced data entries & $\begin{array}{l}\text { The model shows how the data entries in the specification process are reduced. Each } \\
\text { product feature is defined at most, two times by two actors. }\end{array}$ \\
\hline $\begin{array}{c}\text { Elimination of process } \\
\text { steps and handovers }\end{array}$ & $\begin{array}{l}\text { Several activities where information is being reentered, such as the order registration, } \\
\text { have now been eliminated. In this way, the complexity of the specification process is } \\
\text { reduced significantly, information handover is avoided and the likelihoods of errors are } \\
\text { reduced. }\end{array}$ \\
\hline $\begin{array}{c}\text { Capturing customer } \\
\text { requirements }\end{array}$ & $\begin{array}{l}\text { The salesman uses the configuration tool to present different solutions to the } \\
\text { customers. The product configuration is done in process step 1 by the salesman. Now } \\
\text { the salesman only specifies information about the product application (the customer } \\
\text { vew). }\end{array}$ \\
\hline Precise quoations & $\begin{array}{l}\text { All the parts of the product have been identified by the configuration system in process } \\
\text { step 2 and are included in the price calculations, leading to more precise quotations. }\end{array}$ \\
\hline $\begin{array}{c}\text { Technical Know How } \\
\text { build in configuration } \\
\text { system }\end{array}$ & $\begin{array}{l}\text { Technical information about the product is now available in the configuration system, } \\
\text { and characteristics of the materials to be handled, is available to the designers. This } \\
\text { reduces the need of the salesmen for calling the technical office and the designers } \\
\text { contacting salesmen later in the process. }\end{array}$ \\
\hline
\end{tabular}

Table 3: Evaluation of the IPPM modelling technique.

\begin{tabular}{|l|c|c|c|c|c|}
\cline { 2 - 5 } \multicolumn{1}{l|}{} & $\begin{array}{c}\text { Strongly } \\
\text { disagree }\end{array}$ & Disagree & Neutral & Agree & $\begin{array}{c}\text { Strongly } \\
\text { agree }\end{array}$ \\
\hline $\begin{array}{l}\text { In your opinion, would it be possible to identify and gather the } \\
\text { information needed by the company to document the IPPM? }\end{array}$ & & & & 3 & 2 \\
\hline $\begin{array}{l}\text { When you first saw the IPPM model, was it obvious to you } \\
\text { what information was being presented? }\end{array}$ & & & & 3 & 2 \\
\hline Were the purpose and the benefits of the IPPM model obvious? & & & 1 & 3 & 1 \\
\hline $\begin{array}{l}\text { Do you expect it will require little effort to learn to understand } \\
\text { the information on the IPPM model? }\end{array}$ & & 1 & 2 & 1 & 1 \\
\hline $\begin{array}{l}\text { Do you expect it will require little effort to learn to create an } \\
\text { IPPM model? }\end{array}$ & & 3 & 1 & 1 & \\
\hline $\begin{array}{l}\text { In your opinion, would the IPPM model be helpful to } \\
\text { communicate the specification process? }\end{array}$ & & & & 5 & \\
\hline $\begin{array}{l}\text { In your opinion, would it be realistic to use this model by an } \\
\text { industrial company? }\end{array}$ & & & 1 & 4 & \\
\hline $\begin{array}{l}\text { In your opinion, would the information presented by the VSM of } \\
\text { the specification processes be valuable when evaluating the } \\
\text { investment of implementing a configuration tool? }\end{array}$ & & & 1 & 3 & 1 \\
\hline $\begin{array}{l}\text { In your opinion, would the information presented by the VSM of } \\
\text { the sales configuration process be valuable when evaluating the } \\
\text { optimal level of automation in a sales configuration process? }\end{array}$ & & & 1 & 4 & \\
\hline $\begin{array}{l}\text { In your opinion, would the IPPM model be useful for } \\
\text { redesigning the specification process? }\end{array}$ & & & & 4 & 1 \\
\hline $\begin{array}{l}\text { In your opinion, would the IPPM be useful to compare different } \\
\text { scenarios of a future (TOBE) specification process? }\end{array}$ & & & & 5 & \\
\hline $\begin{array}{l}\text { Do you think that the IPPM modeling technique could provide } \\
\text { additional insight into the specification processes relative to a } \\
\text { separate use of process mapping and PVM? }\end{array}$ & & & 1 & 4 & \\
\hline
\end{tabular}




\section{Including Product Features in Process Redesign}

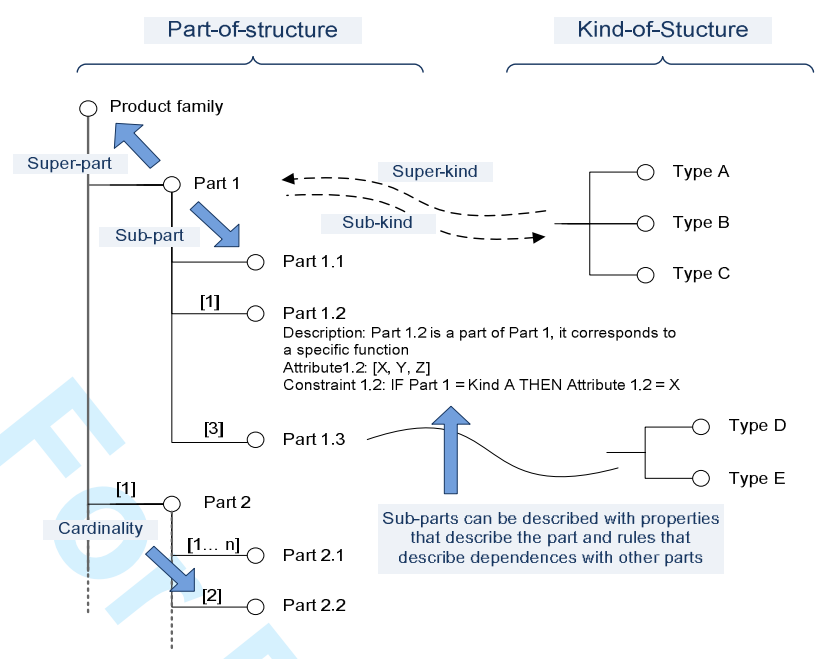

Figure 1: The structure of a PVM (adjusted from Hvam et al., 2008).

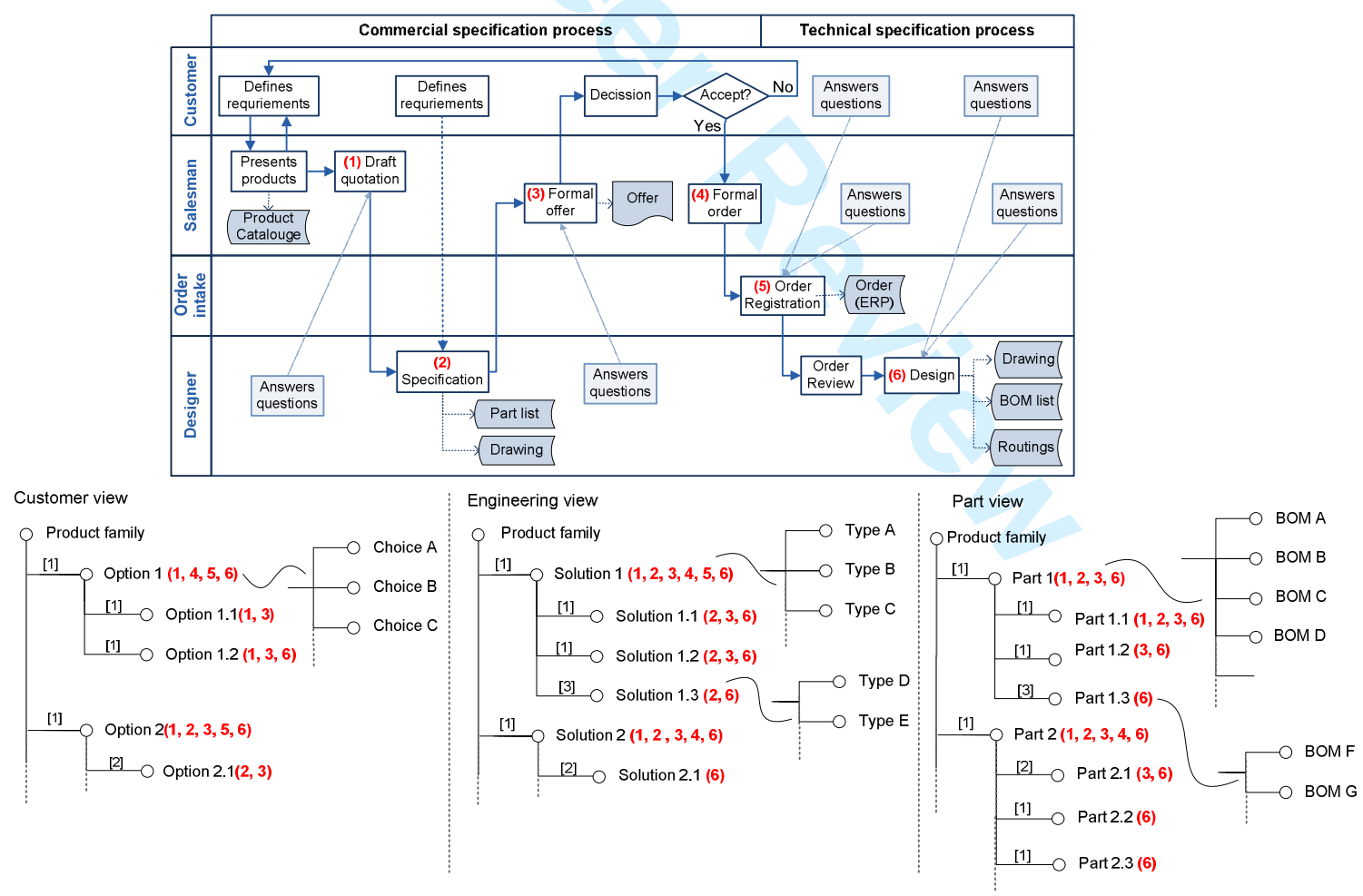

Figure 2: The IPPM. 
$\mathrm{PT}=$ Process Time

$\mathrm{VA}=$ Estimated Value Adding Time

WT = Waiting Time

Lead Time $=\Sigma \mathrm{PT}+\Sigma \mathrm{WT}$

Value Adding Process Time (\%) $=\Sigma \mathrm{VA} / \Sigma \mathrm{PT}$

Value Adding Lead Time (\%) = $\Sigma$ VA/Lead Time

Figure 3: An approach to VSM of the specification process. 


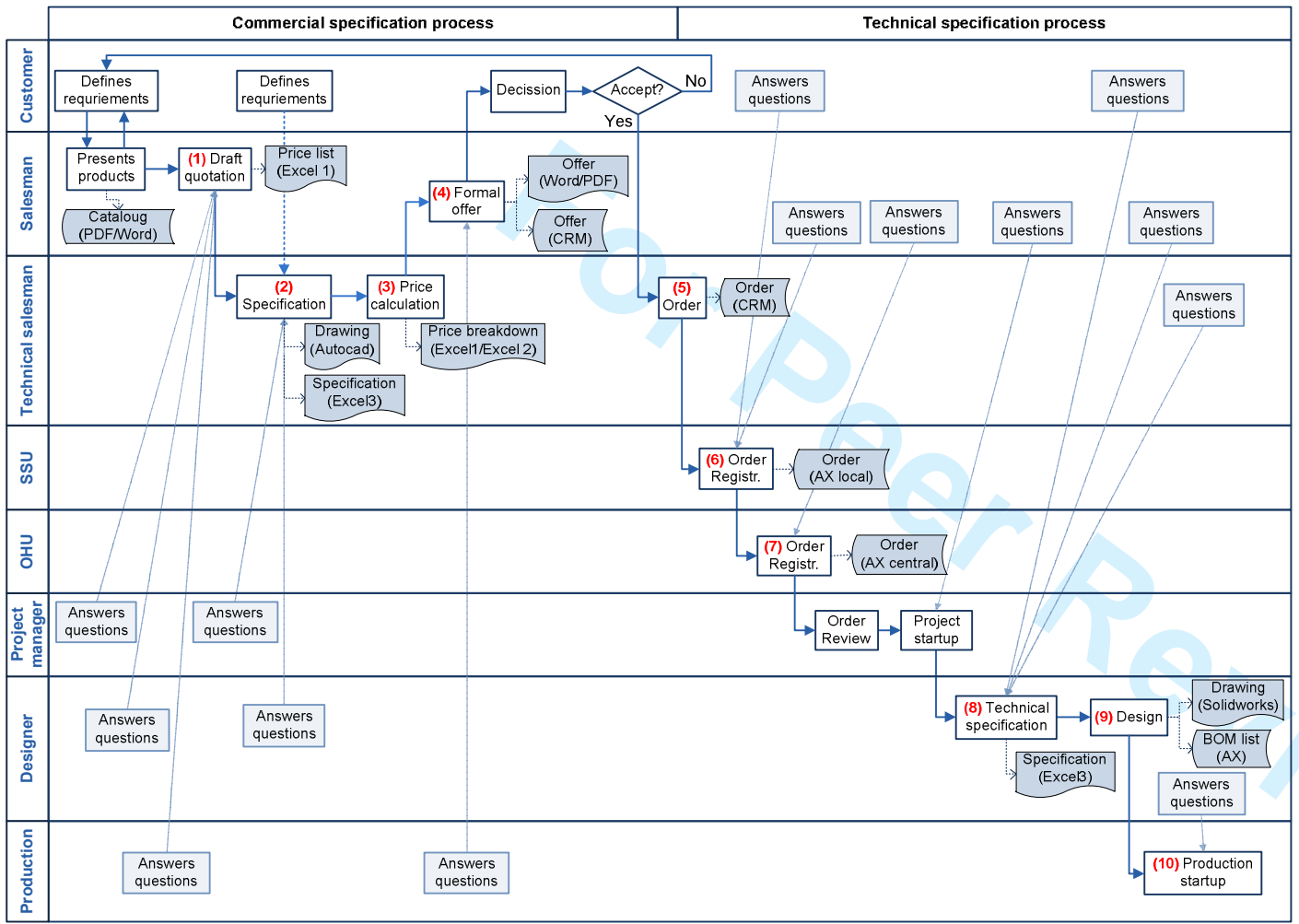

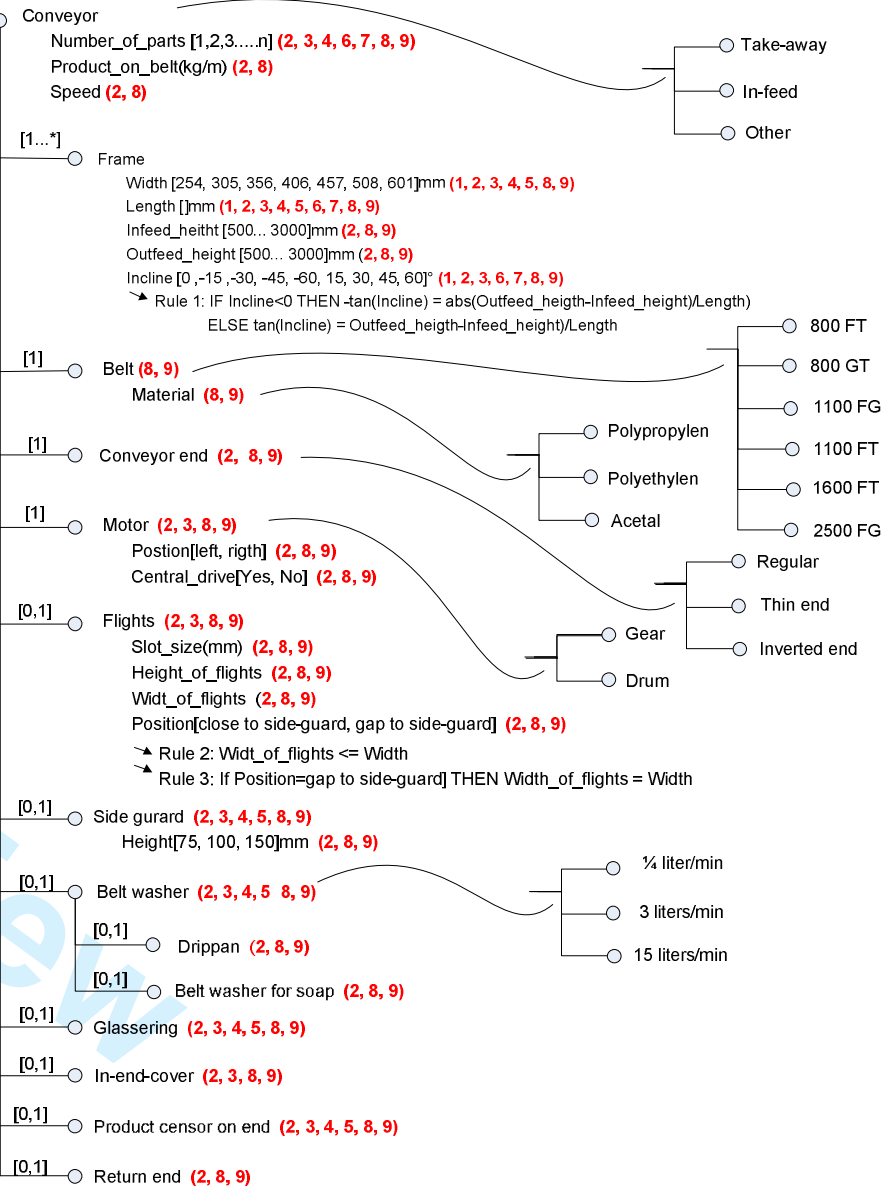

Figure 4: The IPPM for the ASIS specification process of conveyors 
Figure 5: VSM of the ASIS specification process. 
Figure 6: The IPPM for the TOBE specification process of conveyors.

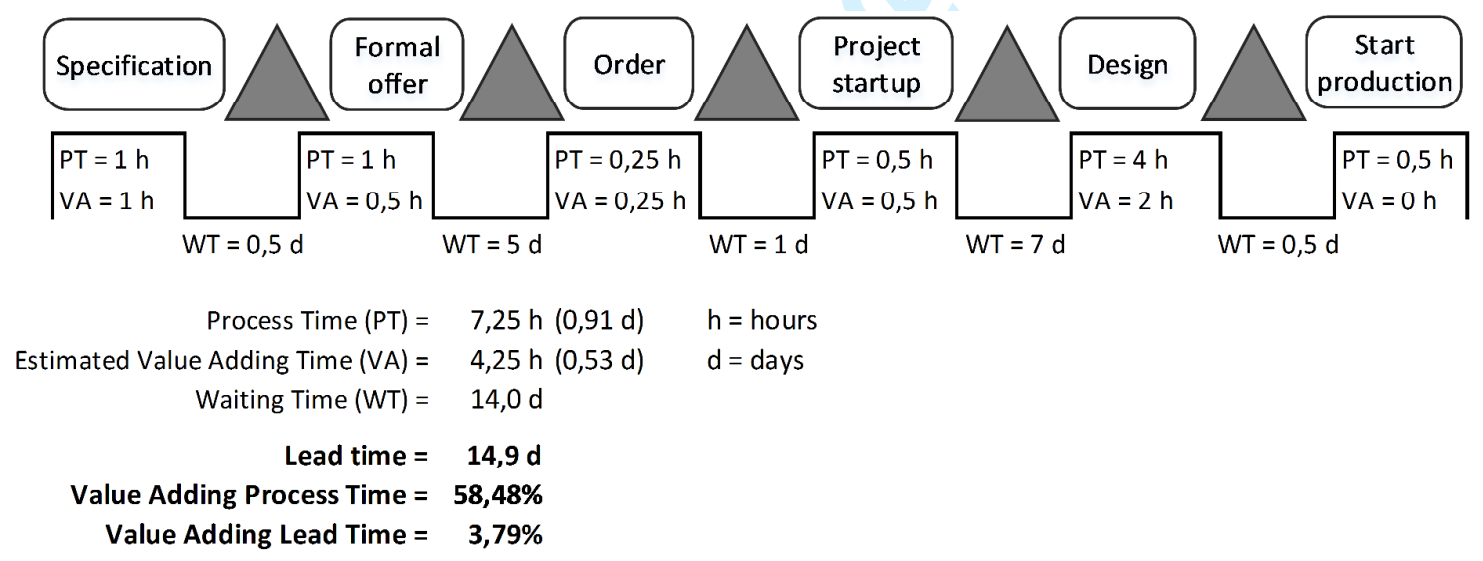

Figure 7: VSM for the TOBE specification process of conveyors. 